\title{
Evidence from Oocyte Expression That the Erythrocyte Water Channel Is Distinct from Band 3 and the Glucose Transporter
}

\author{
Rubin Zhang, Seth L. Alper, ${ }^{\star}$ Bernard Thorens, ${ }^{\star}$ and A. S. Verkman \\ Departments of Medicine and Physiology, Cardiovascular Research Institute, University of California, San Francisco, California \\ 94143-0532; *Molecular Medicine and Renal Units, Department of Medicine, Beth Israel Hospital and Department of Cellular \\ and Molecular Physiology, Harvard Medical School, Boston, Massachusetts 02115; and ${ }^{\ddagger}$ Biology Department, \\ Whitehead Institute, Massachusetts Institute of Technology, Cambridge, Massachusetts 02139
}

\begin{abstract}
It has been proposed that the mercurial-sensitive water transporter in mammalian erythrocytes is the anion exchanger band 3 (AE1) and/or the glucose transporter, band 4.5 (GLUT1). Using a functional assay for water channel expression in Xenopus oocytes (Zhang, R., K. A. Logee, and A. S. Verkman. 1990. J. Biol. Chem. 265:15375-15378), we compared osmotic water permeability $\left(P_{f}\right)$ of oocytes injected with water, reticulocyte mRNA, AE1 mRNA, and GLUT1 mRNA. Injection of oocytes with 5-50 ng of in vitro-transcribed AE1 mRNA had no effect on $\boldsymbol{P}_{\mathrm{f}}$, but increased trans-stimulated ${ }^{36} \mathrm{Cl}$ uptake greater than fourfold in a dinitro-disulfonic stilbene (DNDS)-inhibitable manner. Injection with 1-50 ng of in vitro-transcribed GLUT1 mRNA increased ${ }^{3} \mathrm{H}$-methylglucose uptake $>15$-fold in a cytochalasin B-sensitive manner and increased $P_{\mathrm{f}}$ from $(3.7 \pm 0.4)$ $\times 10^{-4} \mathrm{~cm} / \mathrm{s}\left(\mathrm{SE}, n=16,10^{\circ} \mathrm{C}\right)$ in water-injected oocytes up to $(13 \pm 1) \times 10^{-4} \mathrm{~cm} / \mathrm{s}(n=18)$. Both the increments in sugar and water transport were inhibited by cytochalasin $B(25 \mu \mathrm{M})$ and phloretin ( $0.2 \mathrm{mM}$ ); neither was inhibited by $0.3 \mathrm{mM} \mathrm{HgCl}$. In oocytes injected with 50 ng of rabbit reticulocyte mRNA, the $P_{f}$ of $(18 \pm 2) \times 10^{-4} \mathrm{~cm} / \mathrm{s}(n=18)$ was reduced to $(4.0 \pm 0.6) \times 10^{-4}$ $\mathrm{cm} / \mathrm{s}(n=10)$ by $\mathrm{HgCl}_{2}$, but was not inhibited by DNDS (0.4 $\mathrm{mM}$ ), cytochalasin B or phloretin. Coinjection of reticulocyte mRNA with antisense oligodeoxyribonucleotides against AE1 or GLUT1 did not affect $\boldsymbol{P}_{f}$, but inhibited completely the incremental uptake of ${ }^{36} \mathrm{Cl}$ or ${ }^{3} \mathrm{H}$-methylglucose, respectively. Expression of size-fractionated $\mathrm{mRNA}$ from reticulocyte gave a 2-2.5-kb size for water channel mRNA, less than the 4-4.5-kb size for the $\mathrm{Cl}$ transporter. These results provide evidence that facilitated water transport in erythrocytes is mediated not by bands 3 or 4.5, but by distinct water transport protein(s). ( $J$. Clin. Invest. 1991. 88:1553-1558.) Key words: anion transport - red cell • mRNA expression • mercurial • cytochalasin
\end{abstract}

\section{Introduction}

The plasma membrane of mammalian erythrocytes contains a specialized channel or pore for rapid transport of water $(1,2)$.

Address correspondence to A. S. Verkman, M.D., Ph.D., 1065 Health Sciences East Tower, Cardiovascular Research Institute, University of California, San Francisco, San Francisco, CA 94143-0532.

Received for publication 02 May 1991 and in revised form 27 June 1991

J. Clin. Invest.

(C) The American Society for Clinical Investigation, Inc.

$0021-9738 / 91 / 11 / 1553 / 06 \quad \$ 2.00$

Volume 88, November 1991, 1553-1558
This water channel confers an osmotic water permeability $\left(P_{\mathrm{f}}\right.$ $=0.02-0.05 \mathrm{~cm} / \mathrm{s})^{1}$ much greater than that of synthetic lipid bilayers or biomembranes that lack water channels $(<0.005$ $\mathrm{cm} / \mathrm{s}$ ) (3). Additional evidence supporting the existence of an erythrocyte water channel is a low Arrhenius activation energy for $P_{\mathrm{f}}\left(E_{\mathrm{a}}<5 \mathrm{kcal} / \mathrm{mol}\right)$, a high ratio of osmotic-to-diffusional water permeability $\left(P_{\mathrm{f}} / P_{\mathrm{d}}>3\right)$ and strong inhibition of $P_{\mathrm{f}}$ by mercurial sulfhydryl reagents (1-3). Mercurial-sensitive water channels are also present on plasma and intracellular membranes of kidney proximal $(4,5)$ and collecting tubules $(6-8)$, and amphibian urinary bladder $(6,9,10)$, but not in other cell types including intestine, trachea, placenta, and platelets (3).

Considerable effort has been focused on the identification of mercurial-sensitive water transporting protein(s) in the erythrocyte. Biophysical calculations suggesting the presence of $>2$ $\times 10^{5}$ water channels per erythrocyte have led to assignments of water channel activity to two sulfhydryl-containing proteins: the anion exchanger band $3(\mathrm{AE} 1)$ and the glucose transport protein band 4.5 (GLUT1) $(1,2,11)$. Several laboratories have reported localization of radiolabeled sulfhydryl inhibitors of water transport to band 3 (12-14). Solomon and colleagues have reported a series of functional and pharmacological studies suggesting linkage among erythroid water, urea, and anion transporters $(2,13,15)$. Freeze-etch studies of erythrocyte membranes showed sublimation of water in particle aggregates containing band 3 (16), providing indirect evidence that water might move through band 3 . However, because of the high basal water permeability of reconstituted lipid bilayers and the low maximal density of band 3 molecules in reconstitution experiments, it has not been possible to test directly the hypothesis that band 3 is the erythrocyte water channel.

Fischbarg and colleagues have reported several studies suggesting that $\mathrm{Na}$-independent glucose transporters are water transporters. Osmotic water transport in corneal endothelium and cultured $\mathrm{J} 774$ macrophages was partially inhibited by the glucose transport inhibitors cytochalasin B and phloretin (17, 18). Furthermore, injection of Xenopus oocytes with in vitrotranscribed mRNA encoding GLUT1 produced a small increase in oocyte water permeability (19). These data were consistent with the possibility that GLUT1 may be the primary route for water transport in erythrocytes.

The purpose of this study was to determine the capacities of AE1 and/or GLUT1 to transport water, and to assess their contributions to erythrocyte water transport. Experiments were based on the observation that functional mercurial-sensitive water channels are expressed in Xenopus oocytes microin-

1. Abbreviations used in this paper: $\mathrm{AE} 1$, anion exchanger band 3; DNDS, dinitro-disulfonic stilbene; GLUT1, glucose transport protein band $4.5 ; P_{\mathrm{f}}$, osmotic water permeability. 
jected with mRNA from kidney, toad urinary bladder, or reticulocyte $(20,21)$. We found that the erythroid water transport activity expressed in oocytes was inhibited by mercurials, but not by inhibitors of anion or glucose transport. Specific suppression of $\mathrm{AE} 1$ or GLUT1 activities by coinjection of the corresponding antisense oligonucleotides did not affect reticulocyte mRNA-induced water transport. Expression of in vitrotranscribed AE1 mRNA did not increase water transport. In contrast, mRNA encoding GLUT1 did produce an increase in oocyte water permeability which, though sensitive to inhibitors of glucose transport inhibitors, was insensitive to low concentrations of mercurials. Finally, size fractionation studies were performed to compare the size of reticulocyte mRNA encoding water, anion, and glucose transport activities.

\section{Methods}

Materials. The following materials were obtained from the indicated sources: guanidinium thiocyanate, Fluka AG, Buchs, Switzerland; $\mathrm{CsCl}$ and sucrose, Bethesda Research Laboratories, Gaithersburg, MD; mRNA isolation kit, Pharmacia LKB Biotechnology, Inc., Piscataway, NJ. The antisense oligo-deoxyribonucleotides 5'-GTGGTCCCGCATGTCCCCCAT-3' (anti-murine AE1 [22]) and 5'-CTTGCTGCTGGGCTCCATGGC-3' (anti-GLUT1 [23]) were synthesized on a model 380B DNA synthesizer (Applied Biosystems Inc., Foster City, $\mathrm{CA}$ ) and purified on a Nensorb column (DuPont Co., Wilmington, DE). All other chemicals were purchased from Sigma Chemical Co., St. Louis, MO. Solutions of the inhibitors $\mathrm{HgCl}_{2}$, phloretin, cytochalasin $B$, and DNDS were prepared immediately before use.

$m R N A$ isolation and size fractionation. Reticulocytosis was induced in New Zealand white rabbits $(1-1.5 \mathrm{~kg})$ by withdrawal of 30-40 cc blood for 3 consecutive days to give Hct 20-22 vol \%. The rabbit was exsanguinated on day 6 and the blood was washed twice and the buffy coat was carefully removed. The erythrocyte/reticulocyte layer was suspended in $4 \mathrm{M}$ guanidinium thiocyanate, $25 \mathrm{mM}$ sodium citrate, $0.5 \%$ sarcosyl, $0.1 \mathrm{M}$ mercaptoethanol, pH 7, and homogenized on a Polytron homogenizer. Total RNA was isolated by phenol-chloroform extraction and centrifugation through $\mathrm{CsCl}$ as described previously (20). Poly $\left(\mathrm{A}^{+}\right) \mathrm{RNA}$ (mRNA) was purified twice by affinity chromatography on oligo $(d T)$-cellulose. mRNA was dissolved in water and stored at $-70^{\circ} \mathrm{C}$.

Size fractionation was performed by sucrose gradient centrifugation. $100 \mu \mathrm{g}$ poly $\left(\mathrm{A}^{+}\right)$RNA was added to a $5-25 \%$ sucrose gradien containing $10 \mathrm{mM}$ methylmercuric hydroxide. Gradients were centrifuged for $15 \mathrm{~h}$ at $34,000 \mathrm{~g}$ at $4^{\circ} \mathrm{C}$ in a model SW41 rotor (Beckman Instruments, Inc., Fullerton, CA). Fractions were collected and diluted with an equal volume of DEPC-treated water containing $5 \mathrm{mM}$ mercaptoethanol. mRNA was precipitated in ethanol. Size-fractionated mRNA transferred to nitrocellulose and blotted with ${ }^{32} \mathrm{P}$-labeled oligo $(d T)_{30}$.

Transcription of cDNA encoding band 3 and the erythroid glucose transporter. For preparation of AE1 mRNA, the plasmid pBL (derived from pB3SP4 [22] and from pL2A [24]) encoding murine erythroid AEl was linearized with Hind III in the $3^{\prime}$ noncoding region and transcribed by T7 RNA polymerase as described previously $(24,25)$. For preparation of GLUT1 mRNA, the Bam HI fragment of clone pSGT (26) containing the entire coding region was subcloned into pGEM3 (Promega Biotec, Madison, WI). This new plasmid was linearized with Kpnl and transcribed with SP6 polymerase.

Oocyte injection. Stage V and VI oocytes (1.2-1.3 mm diameter) from Xenopus laevis were isolated as described $(27,28)$ and stored in Barth's buffer (in mM: $\mathrm{NaCl}, 88 ; \mathrm{KCl}, 1 ; \mathrm{MgSO}_{4}, 0.82, \mathrm{Ca}\left(\mathrm{NO}_{3}\right)_{2}$,

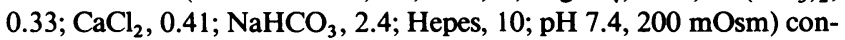
taining benzyl penicillin $(10 \mu \mathrm{g} / \mathrm{ml})$ and streptomycin $(10 \mu \mathrm{g} / \mathrm{ml})$. The follicular cell layer was digested by $2 \mathrm{~h}$ incubation with collagenase (type $1 \mathrm{~A}, 2 \mathrm{mg} / \mathrm{ml}$ ) at $25^{\circ} \mathrm{C}$. Oocytes were washed eight times with Barth's buffer and microinjected with 50-nl samples under high pressure using an automatic injection system (Eppendorf) and sterile femtotips. Oocytes were incubated at $(18 \pm 0.2)^{\circ} \mathrm{C}$ for $68-72 \mathrm{~h}$ before assay with buffer changes at 24 and $48 \mathrm{~h}$.

Water transport assay. Osmotic water permeability of individual oocytes was assayed at $10^{\circ} \mathrm{C}$ from the time course of oocyte swelling in response to a 20-fold dilution of Barth's buffer with distilled water (21). Relative oocyte volume was averaged in 1-s time intervals by a realtime imaging method as described previously. Osmotic water permeability $\left(P_{\mathrm{f}}, \mathrm{cm} / \mathrm{s}\right)$ was calculated from the initial rates of swelling, $\mathrm{d}(V /$ $\left.V_{\mathrm{o}}\right) / d t$, oocyte surface-to-volume ratio $\left(S / V_{\mathrm{o}}=50 \mathrm{~cm}^{-1}\right)$ and partial molar volume of water $\left(V_{\mathrm{w}}=18 \mathrm{~cm}^{3} / \mathrm{mol}\right)$ from the relation, $P_{\mathrm{f}}=[\mathrm{d}(V /$ $\left.\left.V_{\mathrm{o}}\right) / d t\right] /\left[\left(S / V_{\mathrm{o}}\right) V_{\mathrm{w}} \cdot\left(\mathrm{osm}_{\text {out }}-\mathrm{osm}_{\text {in }}\right)\right](21)$, where $\operatorname{osm}_{\text {out }}-\mathrm{osm}_{\text {in }}=190$ mOsm. $\mathrm{d}\left(V / V_{\mathrm{o}}\right) / d t$ was determined from the initial slope of a quadratic polynomial fitted to the first 5 min of the swelling time course.

Anion and glucose transport assay. Uptake of ${ }^{36} \mathrm{Cl}$ or ${ }^{3} \mathrm{H}-3-\mathrm{O}$ methyl-glucose (New England Nuclear, Boston, MA) was measured in groups of six to seven oocytes at $23^{\circ} \mathrm{C}$. Oocytes were incubated in $1 \mathrm{ml}$ of Barth's buffer containing $2 \mu \mathrm{Ci}^{3} \mathrm{H}$-methylglucose $(79 \mathrm{Ci} / \mathrm{mmol}$ ) for glucose uptake or in $1 \mathrm{ml}$ of modified Barth's buffer (chloride replaced by isethionate) containing $1 \mu \mathrm{Ci}^{36} \mathrm{Cl}(750 \mu \mathrm{Ci} / \mathrm{mmol}$ ) (for trans-stimulated anion uptake). Uptake was terminated at set times by aspirating the medium and washing three times with $15 \mathrm{ml}$ of ice cold Barth's buffer containing $0.4 \mathrm{mM}$ DNDS or $0.2 \mathrm{mM}$ phloretin. Washed oocytes were transferred individually to scintillation vials containing 0.5 $\mathrm{ml}$ of $1 \%$ SDS to dissolve the oocyte (1-2 h). $5 \mathrm{ml}$ of scintillation fluid was added for measurement of radioactivity. Uptake was expressed as the percentage of equilibrium uptake calculated assuming oocyte aqueous volumes of 0.9 and $0.6 \mu \mathrm{l}$ for ${ }^{3} \mathrm{H}$-methylglucose and ${ }^{36} \mathrm{Cl}$, respectively.

\section{Results}

Fig. $1 A$ shows the time course of oocyte swelling in response to an osmotic gradient; averaged osmotic water permeability coefficients $\left(P_{\mathrm{f}}\right)$ for measurements performed on a series of oocytes are summarized in Fig. 2. Because the activation energy for $P_{\mathrm{f}}$ is greater for native oocytes $(\sim 10 \mathrm{kcal} / \mathrm{mol})$ than for the expressed water channel ( $<5 \mathrm{kcal} / \mathrm{mol})(20)$, measurements were performed at $10^{\circ} \mathrm{C}$ to maximize the fraction of total $P_{\mathrm{f}}$ due to the expressed water channel. $P_{\mathrm{f}}$ in oocytes microinjected with $50 \mathrm{ng}$ of unfractionated $\mathrm{mRNA}$ isolated from rabbit reticulocytes was $(18 \pm 2) \times 10^{-4} \mathrm{~cm} / \mathrm{s}(\mathrm{SE}, n=18)$, fourfold greater than $P_{\mathrm{f}}$ in water-injected oocytes, $(3.7 \pm 0.4) \times 10^{-4} \mathrm{~cm} / \mathrm{s}(n$ $=16$ ). It was shown previously that $P_{\mathrm{f}}$ in oocytes microinjected with $50 \mathrm{ng}$ of mRNA from brain, muscle, and a series of cultured cell lines was not different from $P_{\mathrm{f}}$ in the water-injected oocytes (20). The increase in $P_{\mathrm{f}}$ due to injection of reticulocyte mRNA was inhibited strongly by inclusion of $0.3 \mathrm{mM} \mathrm{HgCl}_{2}$ in the assay buffer (Fig. 2).

To evaluate the role of AE1 as a water channel, the expression of AE1 from total reticulocyte mRNA was blocked by coinjection of an antisense AE1 oligodeoxyribonucleotide with the reticulocyte mRNA. Figs. $1 A$ and 2 show that the antisense AEl oligonucleotide had no effect on the increase in oocyte $P_{\mathrm{f}}$. Addition of the stilbene inhibitor of anion transport, DNDS, to the assay buffer also did not affect $P_{\mathrm{f}}$. In contrast, the twofold increase in trans-stimulated ${ }^{36} \mathrm{Cl}$ uptake due to $\mathrm{AE} 1$ expression from reticulocyte mRNA was blocked by extracellular DNDS or by coinjection of antisense AE1 oligonucleotide (Fig. $1 \mathrm{~B}$ ).

Microinjection of oocytes with mRNA in vitro-transcribed from AE1 cDNA produced a large, dose-dependent increase in ${ }^{36} \mathrm{Cl}$ uptake (Fig. $1 \mathrm{~B}$ ) as described previously $(24,25)$. The 
A

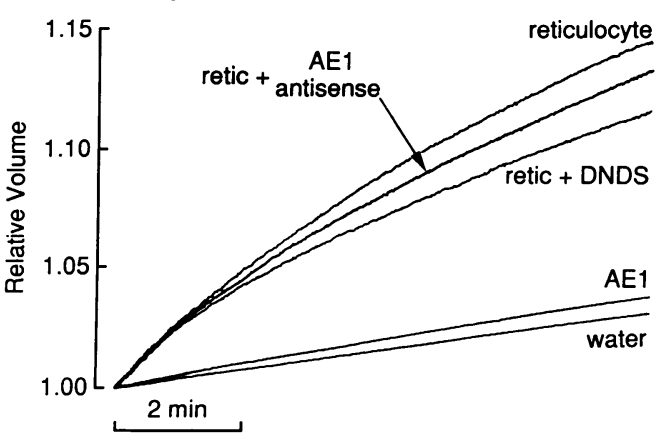

B

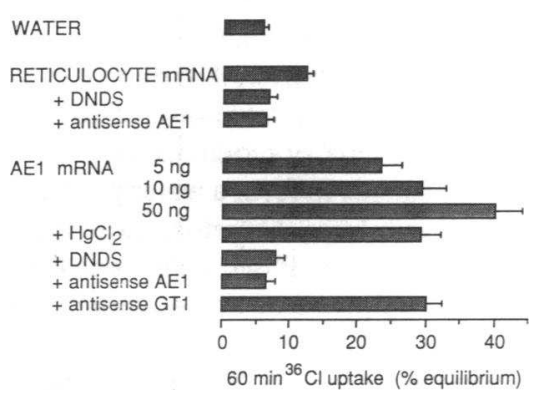

Figure 1. Measurement of water and chloride transport in oocytes microinjected with mRNA isolated from rabbit reticulocyte or from in vitro-transcribed from AE1 cDNA. (A) Time course of oocyte swelling in response to an osmotic gradient measured by image analysis (see Methods). Water permeability was assayed at $10^{\circ} \mathrm{C}, 68-72$ $\mathrm{h}$ after microinjection. Oocytes were injected with $50 \mathrm{nl}$ of water, 50 $\mathrm{ng}$ of in vitro-transcribed AE1 mRNA, or $50 \mathrm{ng}$ of unfractionated reticulocyte mRNA with or without $5 \mathrm{fmol}$ antisense AE1 oligonucleotide (100-fold molar excess, assuming that AE1 represents $0.1 \%$ of reticulocyte mRNA). Water transport in oocytes microinjected with reticulocyte mRNA was measured in the presence and absence of $0.4 \mathrm{mM}$ DNDS in the assay buffer. Data from a series of similar measurements are summarized in Fig. 2. (B) 60 min uptake of ${ }^{36} \mathrm{Cl}$ measured in the presence of an outwardly directed $\mathrm{Cl}$ gradient (transstimulation) as described in Methods. Each point is the mean $\pm \mathrm{SE}(n$ $=10-15$ oocytes) from three separate sets of experiments; externally bound ${ }^{36} \mathrm{Cl}(<10 \%)$, determined from a 0 -time uptake measurement, was subtracted. Oocytes were injected with $50 \mathrm{nl}$ of water, $50 \mathrm{ng}$ of reticulocyte mRNA, or 5-50 ng of band 3 mRNA. For inhibition studies, $10 \mathrm{ng}$ of band $3 \mathrm{mRNA}$ was used. Concentrations were 0.4 $\mathrm{mM}$ DNDS and $0.3 \mathrm{mM} \mathrm{HgCl}$. Amounts of injected antisense oligonucleotide were 1 pmol AE1 ( 100-fold molar excess) and 2 pmol GLUT1.

increase was blocked equally well by DNDS or by coinjection of antisense AE1 oligonucleotide, but not by coinjection with an antisense GLUT1 oligonucleotide. $P_{\mathrm{f}}$ in oocytes coinjected with total reticulocyte mRNA and with in vitro-transcribed AE1 mRNA was not greater than $P_{\mathrm{f}}$ in oocytes injected with reticulocyte mRNA alone (Fig. 2).

A similar set of studies was carried out to evaluate the role of the sodium-independent glucose transporter, GLUT1, in water transport. Fig. $3 \mathrm{~B}$ shows that injection of reticulocyte mRNA caused a significant increase in ${ }^{3} \mathrm{H}$-methylglucose uptake that was blocked equally well by extracellular cytochalasin
B or by coinjection of antisense GLUT1 oligonucleotide. Figs. 2 and $3 A$ additionally reveal that the antisense GLUT1 oligonoucleotide did not affect $P_{\mathrm{f}}$ in oocytes injected with reticulocyte mRNA. Furthermore, extracellular addition of the glucose transport inhibitors cytochalasin B and phloretin did not affect $P_{\mathrm{f}}$.

Microinjection of oocytes with in vitro-transcribed GLUT1 mRNA caused a large, dose-dependent increase in ${ }^{3} \mathrm{H}$ methylglucose uptake, as described previously $(29,30)$. This increase was blocked by cytochalasin $B$ and by coinjection with the antisense GLUT1 oligonucleotide (Fig. 3 B). ${ }^{3} \mathrm{H}-$ Methylglucose uptake was not affected by coinjection of antisense AE1 oligonucleotide. Figs. 2 and $3 \mathrm{~A}$ show that expression of GLUT1 was associated with a significant increase in oocyte $P_{\mathrm{f}}$ that was blocked by cytochalasin B and phloretin. Furthermore, the increment in $P_{\mathrm{f}}$ due to injection of increasing amounts of GLUT1 mRNA was approximately parallel to the increment in ${ }^{3} \mathrm{H}$-methylglucose uptake (Figs. 2 and $3 \mathrm{~B}$ ). These results support the hypothesis of Fischbarg et al. (19) that the glucose transporter GLUT1 can mediate water conductance. Similar results were found for the liver type glucose transporter (GLUT2). $P_{\mathrm{f}}$ in oocytes injected with $50 \mathrm{ng}$ of mRNA encoding GLUT2 was $12 \pm 2 \times 10^{-4} \mathrm{~cm} / \mathrm{s}$ (SE, $n=12$ ).

A $\mathrm{HgCl}_{2}$ dose-response study was carried out to determine the mercurial sensitivity of GLUT1 for transport of glucose and water. Table I shows a roughly parallel dose-dependent inhibition of glucose and water transport with a $K_{\mathrm{I}}$ of $\sim 0.75$ $\mathrm{mM} \mathrm{HgCl} 2$. At $0.3 \mathrm{mM} \mathrm{HgCl}_{2}$, the GLUT1 mRNA-dependent increment in oocyte $P_{\mathrm{f}}$ was inhibited by $<15 \%$, much less than the $>90 \%$ inhibition of $P_{\mathrm{f}}$ in oocytes injected with reticulocyte mRNA. The $K_{\mathrm{I}}$ for inhibition of $P_{\mathrm{f}}$ in oocytes injected with reticulocyte mRNA was $0.05-0.06 \mathrm{mM}$ (not shown). Taken together, these results indicate that the increase in oocyte $P_{\mathrm{f}}$ induced by reticulocyte mRNA has pharmacological properties distinct from that induced by GLUT1 mRNA.

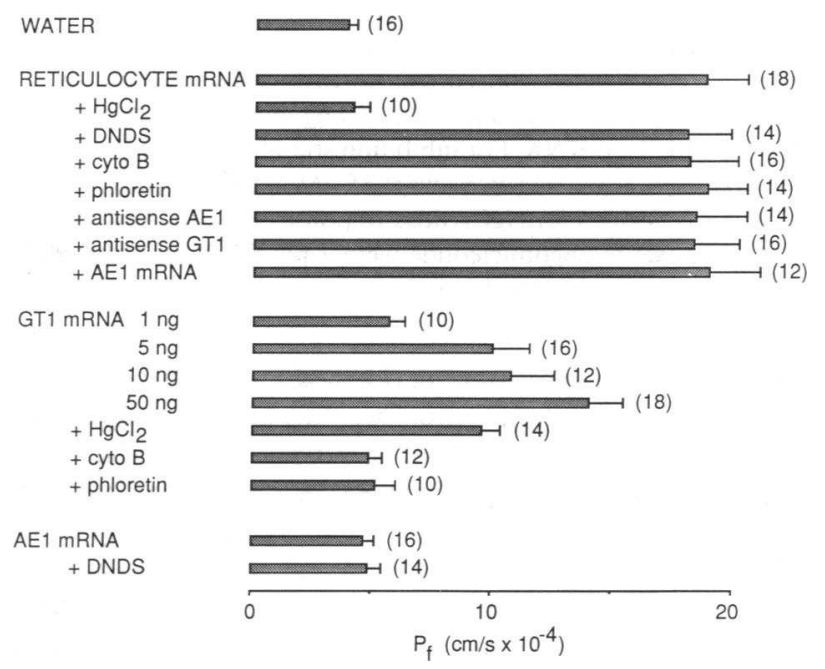

Figure 2. Mean \pm SE osmotic water permeabilities $\left(P_{f}\right)$ in oocytes injected with $50 \mathrm{nl}$ water, $50 \mathrm{ng}$ reticulocyte $\mathrm{mRNA}, 1-50 \mathrm{ng}$ GLUT1 mRNA, or $50 \mathrm{ng} A E 1 \mathrm{mRNA}$. The number of oocytes in each group is given in parentheses. For GLUT1 mRNA inhibition studies, $10 \mathrm{ng}$ was used. Concentrations were $0.3 \mathrm{mM} \mathrm{HgCl}_{2}, 0.4 \mathrm{mM}$ DNDS, 25 $\mu \mathrm{M}$ cytochalasin $\mathrm{B}, 0.2 \mathrm{mM}$ phloretin, $5 \mathrm{fmol}$ antisense $\mathrm{AE} 1$, and 3 fmol antisense GLUT1. For the study in which reticulocyte mRNA and AE1 mRNA were coinjected, 50 and $25 \mathrm{ng}$ were used, respectively. 
A

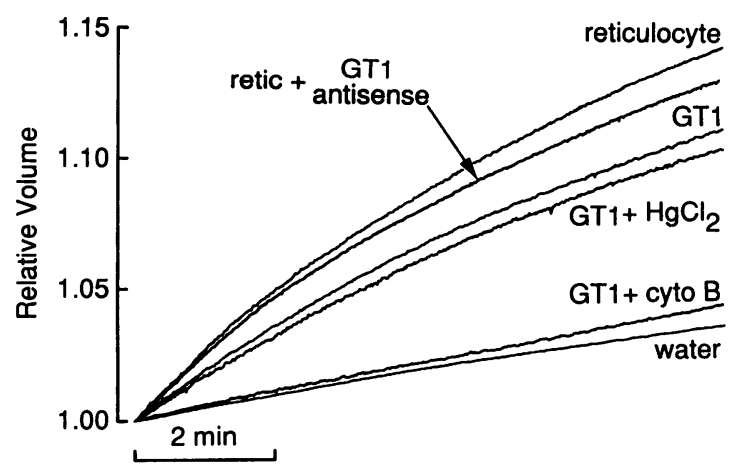

B

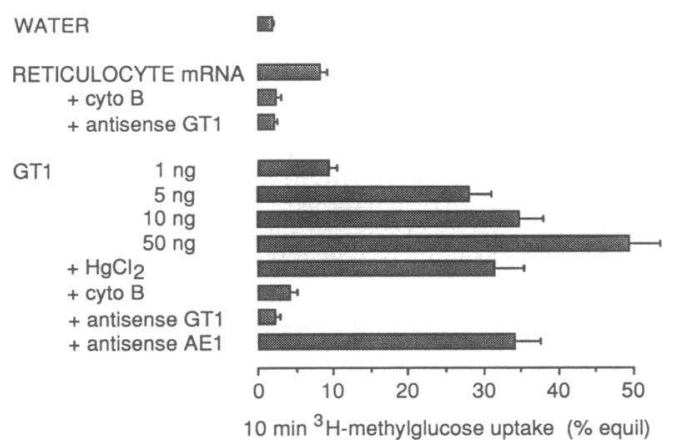

Figure 3. Water and glucose transport in oocytes microinjected with reticulocyte mRNA or in vitro-transcribed mRNA encoding GLUT1. (A) Time course of oocyte swelling was measured as in Fig. $1 \mathrm{~A}$. Oocytes were microinjected with $50 \mathrm{nl}$ water, $50 \mathrm{ng}$ reticulocyte mRNA with or without $3 \mathrm{fmol}$ antisense GLUT1 ( 100-fold molar excess, assuming that GLUT1 represents $0.03 \%$ of reticulocyte mRNA), or $50 \mathrm{ng}$ of GLUT1 mRNA. $\mathrm{HgCl}_{2}(0.3 \mathrm{mM})$ or cytochalasin B $(25 \mu \mathrm{M})$ were present in the assay buffer where indicated. Data from a series of measurements are summarized in Fig. 2. (B) $10 \mathrm{~min}$ uptake of ${ }^{3} \mathrm{H}$-methylglucose (mean $\pm \mathrm{SE}, n=10-15$ oocytes) in three separate sets of experiments was measured as described in Methods. Oocytes were injected with $50 \mathrm{nl}$ water, $50 \mathrm{ng}$ of reticulocyte mRNA, or 1-50 ng GLUT1 mRNA. For inhibition studies, $10 \mathrm{ng}$ of GLUT1 mRNA was used. Concentrations were $25 \mu \mathrm{M}$ cytochalasin B and 0.3 $\mathrm{mM} \mathrm{HgCl} 2$ (see Table I for $\mathrm{HgCl}_{2}$ dose-response relation). Amounts of injected antisense oligonucleotide were 2 pmol (GLUT1) $(\sim 100$ fold molar excess) and 1 pmol (AE1).

Fractionation studies were performed to compare the sizes of mRNA encoding water, glucose, and anion transporters. Fig. 4 shows the relative increase in water, ${ }^{3} \mathrm{H}$-methylglucose, and ${ }^{36} \mathrm{Cl}$ transport resulting from expression of mRNA size fractions from a sucrose gradient. The size of gradient fractions was determined by Northern Blot analysis. In one set of experiments typical of three, anion and glucose transport expression were maximal in fractions corresponding to $4-4.5 \mathrm{~kb}$ and 2-2.5 kb, respectively, consistent with previously reported transcript sizes $(23,24)$. Water transport was expressed in the range $1-3 \mathrm{~kb}$ and maximally by the $2-2.5-\mathrm{kb}$ fraction.

\section{Discussion}

The goal of this study was to determine the role of anion and glucose transporters in facilitated erythrocyte water transport.
Although several lines of evidence have been presented to support roles for band 3 and band 4.5 in erythrocyte water transport, direct evaluation has not been possible. This is due in part to the lack of selective inhibitors of water transport and, in part, to the unreliability of reconstitution studies given the relatively high water permeability of lipid bilayers. In addition, an integral role of membrane lipid components in water permeability has been proposed $(31,32)$, making uncertain the application of classical protein chemical and molecular biological approaches to the elucidation of water channel structure.

The Xenopus oocyte can effectively express erythroid water transporters by microinjection of unfractionated mRNA isolated from reticulocytes. Reticulocyte mRNA rather than mRNA from spleen or cultured cell lines was used to ensure the presence of mRNA encoding the erythroid water transporter. The water transporter expressed in oocytes had pharmacological and biophysical properties similar to those of the native erythrocyte $(1,2)$, suggesting that the increased $P_{\mathrm{f}}$ is attributable to the erythrocyte water transporter. Alternative explanations for the increased $P_{\mathrm{f}}$, including activation of an endogenous Xenopus water transport gene, or reorganization of endogenous oocyte membrane proteins to form a water pore, remain formal, though unlikely possibilities. Therefore the erythrocyte water channel is probably a protein. Based on the size fractionation data, the protein is composed of one or more subunits encoded by mRNA of size $\sim 2-2.5 \mathrm{~kb}$.

Oocytes microinjected with reticulocyte mRNA expressed $\mathrm{AE} 1$ as assayed by stilbene-sensitive ${ }^{36} \mathrm{Cl}$ uptake. $\mathrm{AE} 1$ expression was effectively blocked by coinjection with an antisense 21-mer oligodeoxyribonucleotide complementary to the murine erythroid AE1 translational initiation site and extending 18 bases in the 3 -direction. Based on studies of globin mRNA expression $(33,34)$, a 100 -fold excess of antisense AE1 oligonucleotide over AE1 mRNA was chosen. There was no effect on water transport when $\mathrm{AE} 1$ expression was blocked in oocytes injected with reticulocyte mRNA. In addition, expression of $A E 1$ using in vitro-transcribed AE1 mRNA caused a large increase in stilbene-sensitive ${ }^{36} \mathrm{Cl}$ uptake but no increase in oocyte water permeability. There was no effect of the potent stilbene DNDS on water transport in oocytes microinjected with mRNA from reticulocyte or transcribed in vitro from AE1 cDNA. Moreover, water transport in oocytes coinjected with reticulocyte and band 3 mRNA was not different from that in oocytes injected with reticulocyte mRNA alone.

Table I. Inhibition by $\mathrm{HgCl}_{2}$ of GLUT1-mediated Water and Hexose Transport

\begin{tabular}{ccc}
\hline$\left[\mathrm{HgCl}_{2}\right]$ & \multicolumn{1}{c}{$P_{\mathrm{f}}$} & ${ }^{3} \mathrm{H}-$ Methylglucose uptake \\
\hline$m M$ & $c m / s \times 10^{-4}$ & $\%$ \\
0.0 & $10.0 \pm 1.3$ & $35.0 \pm 4.0$ \\
0.3 & $8.7 \pm 1.0$ & $29.0 \pm 3.0$ \\
0.6 & $7.1 \pm 1.2$ & $22.0 \pm 3.0$ \\
0.9 & $5.3 \pm 0.8$ & $12.0 \pm 2.0$ \\
1.2 & $4.5 \pm 0.5$ & $7.0 \pm 0.7$ \\
1.5 & $3.9 \pm 0.5$ & $4.4 \pm 0.5$ \\
\hline
\end{tabular}

Each data point is the mean \pm SE for measurements performed on six to eight oocytes injected with $10 \mathrm{ng}$ of GLUT1 mRNA. Oocyte $P_{\mathrm{f}}$ and ${ }^{3} \mathrm{H}$-methylglucose uptake (percent equilibrium value) were measured as described in Methods. $\mathrm{HgCl}_{2}$ was present in the assay buffer. 


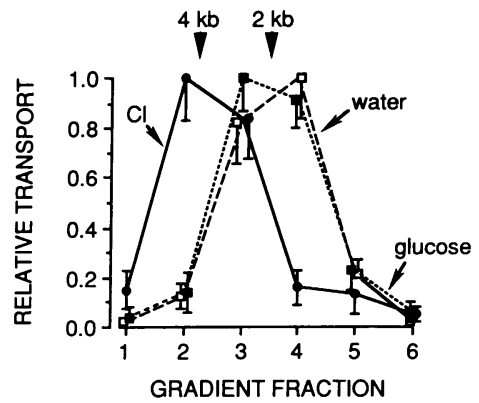

Figure 4. Water, glucose, and chloride transport in oocytes injected with sizefractionated mRNA from rabbit reticulocyte. Relative transport rates of ${ }^{36} \mathrm{Cl},{ }^{3} \mathrm{H}$ methylglucose, and water in oocytes injected with mRNA size fractions from a $5-25 \%$ sucrose gradient. Background transport rates determined in water-injected oocytes were subtracted. The positions of the 2- and 4-kb markers were determined from Northern blot analysis. Data shown are mean \pm SE for six to eight oocytes (for each measurement) in one set of size fractionation studies typical of three.

Solomon and co-workers have proposed that an erythroid water channel may form at the junction of a band 3 multimer (2). However, the apparent surface density of heterologous band 3 expressed in a $1-\mathrm{mm}$ oocyte is $100-1,000$-fold lower (25) than that of band 3 in the erythrocyte (35). Thus, it is possible that heterologous band 3 in the oocyte surface membrane never forms oligomeric assemblies of high enough order to create such "interstitial" water channels. Although this possibility might explain the lack of increase in water permeability by AE 1 mRNA, it is not consistent with the antisense experiments in which reticulocyte mRNA-induced water permeability was not affected by blocking AE1 mRNA expression. In addition, fractionation of reticulocyte mRNA indicated that the mRNA encoding $\mathrm{HgCl}_{2}$-sensitive water transport activity is approximately half the size of the single size class of erythroid AE 1 mRNA. These results provide strong evidence that band 3 is not the erythroid water transporter.

Because the single channel water permeability of biological water channels is not known, and because classical hydrodynamic theory probably does not apply to narrow water channels, there may be considerably fewer than $10^{5}$ water channels per erythrocyte. The data showing preferential localization of sulfhydryl water channel inhibitors to band 3(13-15) confirms that band 3 has reactive $-\mathrm{SH}$ groups, but does not prove that band 3 is a water channel. Similarly, studies of overlapping specificities of low-affinity inhibitors are difficult to interpret in terms of protein function $(13,15)$.

Microinjection of GLUT1 mRNA into oocytes caused a large increase in cytochalasin B-inhibitable uptake of ${ }^{3} \mathrm{H}$ methylglucose, corresponding to a glucose permeability of 2 $\times 10^{-5} \mathrm{~cm} / \mathrm{s}$. This was accompanied by a significant increase in water transport by up to a permeability coefficient of $9 \times 10^{-4}$ $\mathrm{cm} / \mathrm{s}$. The increase in oocyte water permeability was blocked by the glucose transport inhibitors phloretin and cytochalasin. However, the apparent $K_{\mathrm{I}}$ for inhibition of GLUT1-related water permeability by $\mathrm{HgCl}_{2}$ was $>10$-fold greater than that for reticulocyte mRNA-induced water permeability. Therefore GLUT1 mediates a significant water conductance that differs pharmacologically from that of the erythrocyte water channel.

The physiological role of the GLUT1-mediated water conductance was examined by coinjection of oocytes with reticulocyte mRNA and a 21-mer antisense GLUT1 oligodeoxyribonucleotide directed against the mRNA sequence extending from three bases $5^{\prime}$ to the translational initiation site to 15 bases beyond the initiation site in the $3^{\prime}$ direction. Antisense GLUT1 effectively blocked expression of functional glucose transporters but did not affect the water permeability of oocytes injected with reticulocyte mRNA. Glucose transport inhibitors did not affect water transport in the reticulocyte mRNA-injected oocytes at concentrations that blocked both water and glucose transport in oocytes injected with GLUT1 mRNA. These data suggest that water conductance mediated by GLUT1 may contribute only a small fraction of the water permeability in erythrocytes. This conclusion is supported by an estimate of the erythrocyte water permeability attributable to glucose transporters. From the ratio of incremental water and glucose permeability coefficients in oocytes microinjected with GLUT1 mRNA, and from an erythrocyte glucose permeability of 5 $\times 10^{-8} \mathrm{~cm} / \mathrm{s}(36,37)$, the water permeability contributed to the erythrocyte by GLUT 1 would be $2 \times 10^{-6} \mathrm{~cm} / \mathrm{s}, \sim 0.01 \%$ of erythrocyte water permeability $(0.02 \mathrm{~cm} / \mathrm{s})$. Similar calculations in nonerythroid cells suggest that the water conductance of GLUT1 or GLUT2 is probably too small to provide a major route for plasma membrane water transport. However it must be emphasized that these calculations are based on the assumption that expressed GLUT1 or GLUT2 in oocytes functions in a similar manner to GLUT1 or GLUT2 in native cells.

Our antisense experiments were performed with reticulocyte mRNA and thus do not directly address the role of anion and glucose transporters in water transport in kidney. Mercurial-sensitive water channels are present on the apical membrane of the vasopressin-stimulated kidney collecting tubule and on the apical membrane of proximal tubule (3). However, sodium-independent glucose transporters are basolateral membrane proteins in kidney collecting tubule and proximal tubule, and are not present on apical membranes (38). AE1 has been detected only in the basolateral membrane of a subset of intercalated cells (39). Band 3-like anion exchange activity is not present on the apical membrane of collecting tubule principal cells (40) and is weakly present on the apical membrane of proximal tubule; in addition, AE gene family polypeptides have not yet been detected in these membranes. Therefore, it is unlikely that apical membrane anion and glucose transporters provide an important route for water movement in kidney proximal or collecting tubules.

\section{Acknowledgments}

We thank Dr. Dennis Ausiello for advice and critical reading of this manuscript, Dr. Ana Maria Garcia for the plasmid pBL, Dr. V. Lingappa for advice and isolation of oocytes, and Katherine Logee for technical support.

This work was supported by grants DK35124, DK39354, DK39249, and HL42368 from the National Institutes of Health and a grant from the National Cystic Fibrosis Foundation. Dr. Zhang is a fellow of the American Heart Association. Dr. Verkman is an established investigator of the American Heart Association.

\section{References}

1. Macey, R. I. 1984. Transport of water and urea in red blood cells. Am. J. Physiol. 246:C195-C203.

2. Solomon, A. K., B. Chasan, J. A. Dix, M. F. Lukacovic, M. R. Toon, and A. S. Verkman. 1984. The aqueous pore in the red cell membrane: band 3 as a channel for anions, cations, non-electrolytes and water. Ann. NY Acad. Sci. 414:79-124.

3. Verkman, A. S. 1989. Mechanisms and regulation of water permeability in renal epithelia. Am. J. Physiol. 257:C837-C850.

4. Verkman, A. S., P. Weyer, D. Brown, and D. A. Ausiello. 1989. Functional water channels are present in clathrin coated vesicles from bovine kidney but not from brain. J. Biol. Chem. 264:20608-20613. 
5. Ye, R., L.-B. Shi, W. Lencer, and A. S. Verkman. 1989. Functional colocalization of water channels and proton pumps on endocytic vesicles from proximal tubule. J. Gen. Physiol. 93:885-902.

6. Brown, D. 1989. Membrane recycling and epithelial cell function. Am. J. Physiol. 256:F1-F12.

7. Handler, J. S. 1988. Antidiuretic hormone moves membranes. Am. J. Physiol. 255:F375-F382.

8. Verkman, A. S., W. I. Lencer, D. Brown, and D. A. Ausiello. 1988. Endosomes from kidney collecting tubule cells contain the vasopressin-sensitive water channel. Nature (Lond.) 333:268-269.

9. Shi, L. B., and A. S. Verkman. 1989. Very high water permeability in vasopressin-dependent endocytic vesicles in toad urinary bladder. J. Gen. Physiol. $94: 1101-1115$.

10. Shi, L. B., Y.-X. Wang, and A. S. Verkman. 1990. Regulation of the formation and water permeability of endosomes from toad bladder granular cells. J. Gen. Physiol. 96:789-808.

11. Jung, E. K., J. J. Chin, and C. Y. Jung. 1986. Structural basis of human erythrocyte glucose transporter function in reconstituted system. J. Biol. Chem. 261:9155-9160.

12. Benga, G., O. Popescu, V. Borza, V. I. Pop, A. Muresan, I. Mocsy, A Brain, and A. Wriggleworth. 1986. Water permeability in human erythrocytes: identification of membrane proteins involved in water transport. Eur. J. Cell Biol. 41:252-262.

13. Ojcius, D. M., and A. K. Solomon. 1988. Sites of p-chloromercuribenzene sulfonate inhibition of red cell urea and water transport. Biochim. Biophys. Acta. 942:73-82.

14. Brown, P. A., M. D. Feinstein, and R. I. Sha'afi. 1975. Role of erythrocyte band 3 in water transport. Nature (Lond.). 254:523-525.

15. Janoshazi, A., and A. K. Solomon. 1989. Interaction among anion, cation and glucose transport proteins in the human red cell. J. Membr. Biol. 112:25-37.

16. Pinto da Silva, P. 1973. Membrane intercalated particles in human erythrocyte ghosts: sites of preferred passage of water molecules at low temperature. Proc. Natl. Acad. Sci. USA. 70:1339-1343.

17. Fischbarg, J. 1988. On the possible permeation of water across the glucose transporter. Mol. Cell. Biochem. 82:107-111.

18. Fischbarg, J., K. Kuang, J. Hirsch, S. Lecuona, L. Rogozinski, S. C. Silverstein, and J. Loike. 1989. Evidence that the glucose transporter serves as a water channel in J774 macrophages. Proc. Natl. Acad. Sci. USA. 86:8397-8401.

19. Fischbarg, J., K. Kuang, J. C. Vera, S. Arant, S. C. Silverstein, J. Loike, and M. Rosen. 1990. Glucose transporters serve as water channels. Proc. Natl. Acad. Sci. USA. 87:3244-3247.

20. Zhang, R., K. A. Logee, and A. S. Verkman. 1990. Expression of mRNA coding for kidney and red cell water channels in Xenopus oocytes. J. Biol. Chem. 265:15375-15378.

21. Zhang, R., and A.S. Verkman. 1991. Water and urea permeability properties of Xenopus oocytes: expression of mRNA from toad urinary bladder. Am. J. Physiol. 260:26-34.

22. Kopito, R. R., and H. F. Lodish. 1985. Primary structure and transmembrane orientation of the murine anion exchange protein. Nature (Lond.). 316:234-238.
23. Birnbaum, M. J., H. C. Haspel, and O. M. Rosen. 1986. Cloning and characterization of a cDNA encoding the rat brain glucose-transporter protein. Proc. Natl. Acad. Sci. USA. 83:5784-5788.

24. Brosius, F. C., S. L. Alper, A. M. Garcia, and H. F. Lodish. 1989. The major kidney band 3 gene transcript predicts an amine-terminal truncated band 3 polypeptide. J. Biol. Chem. 264:7784-7787.

25. Garcia, A. M., and H. F. Lodish. 1989. Lysine-539 of human band 3 is not essential for ion transport or inhibition by stilbene disulfonates. J. Biol. Chem. 264:19607-19613.

26. Mueckler, M., and H. F. Lodish. 1986. The human glucose transporter can insert post translationally into microsomes. Cell. 44:629-637.

27. Dascal, N. 1987. The use of Xenopus oocytes for study of ion channels. CRC Crit. Rev. Biochem. 22:317-373.

28. Sigel, R. 1990. Use of Xenopus oocytes for the functional expression of plasma membrane proteins. J. Membr. Biol. 117:201-221.

29. Vera, J. C., and O. M. Rosen. 1989. Functional expression of mammalian glucose transport in Xenopus laevis oocytes: evidence for cell-dependent insulin sensitivity. Mol. Cell. Biol. 9:4187-4195.

30. Thorens, B., H. K. Sarkar, H. F. Kaback, and H. F. Lodish. 1988. Cloning and functional expression in bacteria of a novel glucose transporter present in liver, intestine, kidney and beta-pancreatic islet cells. Cell. 55:281-290.

31. Dix, J. A., D. A. Ausiello, C. Y. Jung, and A. S. Verkman. 1985. Target analysis studies of red cell water and urea transport. Biochim. Biophys. Acta. 821:243-252.

32. Benga, G., O. Popescu, and V. I. Pop. 1983. Water exchange through erythrocytes membranes: nuclear magnetic resonance studies on the effect of inhibitors and of chemical modification of human membranes. Cell Biol. Int. Rep. 7:807-818.

33. Marcus-Sekura, C. J. 1988. Techniques for using antisense oligodeoxyribonucleotides to study gene expression. Anal. Biochem. 172:289-295.

34. Melton, D. A. 1985 . Injected anti-sense RNA's specifically block messenger RNA translation in vivo. Proc. Natl. Acad. Sci. USA. 82:144-148.

35. Eylar, E. H., M. A. Madoff, O. V. Brody, and J. L. Onclay. 1962. The contribution of sialic acid to the surface charge of the erythrocyte. J. Biol. Chem. 237:1991-2000.

36. Brahm, J. 1982. Kinetics of glucose transport in human erythrocytes. $J$. Physiol. (Lond.). 339:339-354.

37. Helgerson, A. L., and A. Carruthers. 1989. Analysis of protein-mediated 3-O-methylglucose transport in rat erythrocytes: rejection of alternating conformational carrier model for sugar transport. Biochemistry. 28:4580-4594.

38. Thorens, B., H. F. Lodish, and D. Brown. 1990. Differential localization of 2 glucose transporter isoforms in rat kidney. Am. J. Physiol. 259:C286-C294.

39. Alper, S. L., J. Natale, S. Gluck, H. F. Lodish, and D. Brown. 1989. Subtypes of intercalated cells in rat kidney collecting duct defined by antibodies against the erythroid band 3 and renal vacuolar $\mathrm{H}^{+}$-ATPase. Proc. Natl. Acad. Sci. USA. 86:5429-5433.

40. Weiner, I. D., and L. L. Hamm. 1991. Regulation of Cl/ $/ \mathrm{HCO}_{3}$ exchange in rabbit cortical collecting tubule. J. Clin. Invest. 87:1553-1558. 